\title{
Central Anatolia in the Nineteenth and Eighteenth Centuries BC
}

At the beginning of the second millennium BC, certain sites in central Anatolia, such as Açemhöyük and Kültepe, underwent considerable changes and attracted Assyrian merchants from the southeast. These sites have been excavated for several decades now. They have yielded abundant findings and have allowed us to better understand the environment and material culture of the societies indigenous to the region. The earliest written sources discovered in Anatolia are foreign: they belong to the archives of merchants from Aššur, who settled at the city of Kaniš in the Igth and I8th centuries BC. Kaniš, whose modern name is Kültepe, is located nearby the modern city of Kayseri. Although these documents record the trade relations between Assyrians and Anatolians, they also indirectly document the political organization of Anatolia and its constituent states. To reconstruct the history of a region based primarily on foreign sources necessarily limits the results: we are restricted to those areas of activity, within which the Assyrian merchants operated, and even within these areas, we get a very partial and fragmentary account of events. For example, the Assyrians never named the rulers of the different city-states that they resided in. Fortunately, the few surviving archives belonging to Anatolians offer a more detailed account.

The period on which this article focuses is several centuries earlier than the founding of the Mittani state; in examining this era we would be hard pressed to learn, from the Anatolian point of view, something about the state's origins or the circumstances of its rise to power. This study aims instead to paint a picture of the history and organization of Anatolia in the first centuries of the second millenium BC. A synoptic description of the Anatolian region and its resources during this period will permit us to better understand the political and economic organization of the small Anatolian states and to better analyze the different conflicts that set them against one another during the period documented in the Old Assyrian archives. In the kārum of Kaniš, the Assyrians interacted regularly with Anatolians as well as other foreign merchants, including the Hurrians, who would later found the state of Mittani.

\footnotetext{
* Director of Research at the CNRS, ArScAn-Histoire et archéologie de l'Orient cunéiforme, Maison RenéGinouvès, Archéologie et Ethnologie, Nanterre.
} 


\section{Anatolia and its resources at the beginning of the second millenium}

Hundreds of sites dating to the Bronze Age have been excavated in Anatolia. Nevertheless, only three sites from the Middle Bronze are known by their ancient names: Kültepe, in ancient times called Kaniš, Boğazköy, formerly Hattuš(a), and Alişar, which seems to have once been known as Amkuwa. ${ }^{I}$ Although some sites, like Kültepe, have been excavated for over half a century, there have been, until now, very few attempts at a scholarly synthesis of the findings. Our understanding of material culture, society, and the political organization of sites in Anatolia regularly improves, as does our knowledge of the chronological context of archaeological finds. The development of different sites and their importance was directly linked to their geographic location.

\subsection{The Anatolian space}

Anatolia consists of a central plateau with clay deposits that was shaped by numerous volcanic formations and lacustrine depressions, bordered to the north and south by mountain ranges. The Asian peninsula of Turkey encompasses several geographic zones, all of which were more or less populated during the Middle Bronze Age in the first half of the second millennium BC. ${ }^{2}$

To the north of the Anatolian plateau, the region bordering the Black Sea, there are large areas covered by woods and rich deposits of copper and silver, especially in the Pontic chain to the east. In this area there are relatively few urban centers that date to the Bronze Age, with the exception of the plain between the Kizilırmak and the Yessilırmak. ${ }^{3}$ In the West, there are also only a few major sites inhabited during this time period (see below).

The Anatolian plateau takes up the major part of the Asian peninsula of Turkey. The Kizilirmak flows through its central part, which was densely populated during the Bronze Age; the river serves as a natural border. The most important sites of the Middle Bronze age were located in the fertile plane nestled along river bends. To the west of the Kizilirmak, the soil is drier and there are fewer inhabited sites. To the southwest, in the irrigated plane of Konya there were also fewer settlements, mainly inhabited by farmers and shepherds. To the southeast of the Kizılirmak, in the plane of Kayseri, Kültepe was the most important among a number of settlements that were occupied during the Middle Bronze age. 4

The long range of the Taurus Mountains also forms a natural border between the Anatolian plateau and Cilicia to the south, as well as the Arab plateau to the southeast. 5 The

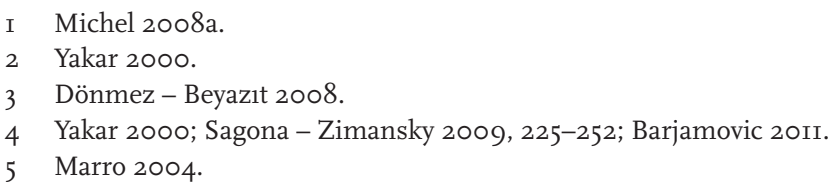


plains of Göksun, Elazı ̆̆ and Elbistan, irrigated by numerous waterways, contain a concentration of smaller Bronze Age sites; these villages, inhabited by farmers, seem to have been oriented toward the Euphrates rather than toward Central Anatolia. The Assyrian caravans coming from Mesopotamia had to cross the Taurus at one of the few mountain passes, but they also had to travel through very densely forested land. To the southeast of the Taurus, the Euphrates constituted an additional natural border. ${ }^{6}$ The cities situated on the other side of the river, although strictly speaking not a part of Anatolia, nevertheless participated in the Assyrian trade network, even though the major commercial exchanges only occurred once the Euphrates had been crossed.

\subsection{Transportation in Anatolia}

The Anatolian plateau itself did not pose any major problems for the transportation of persons and goods; the areas close to the mountain ranges and rivers, however, were difficult to access and to cross. The waterways, depending on their size, depth, and the rapidity of their currents, were either crossed at a ford or with the help of a ferry or a bridge; one group of texts records the costs of using various river crossings.7 Guarded toll bridges spanned smaller streams, while travelers who crossed the Euphrates had to use ferries or small boats that were put at their disposal. ${ }^{8}$ Travelling through the arid steppes and mountain ranges posed other problems that were potentially dangerous to men, animals and the goods they were transporting, and thus certain precautions had to be taken. Accounts recording the employment of carriers and the renting of beasts of burden indicate that crossing the mountains was costly and difficult. Additional men had to be hired to protect against the bands of thieves that plied their trade in the mountains, stealing from and sometimes killing the passing merchants. ${ }^{9}$ The trade agreements concluded between the Anatolian rulers and the Assyrians defined waterways and mountains as dangerous areas. A treaty signed between the Assyrians and the Anatolian authorities of Hahhum, a city on the Euphrates, addresses losses on the river itself, in the surrounding mountains, and anywhere within the lands of the local sovereign. ${ }^{\mathrm{I0}}$ Crossing the Anti-Taurus and Taurus was especially perilous for caravans coming from Aššur. ${ }^{\text {II }}$

The Anatolian climate, continental in nature, featured hot and dry summers contrasted with cold winters and heavy drifts of snow until well into springtime. These climatic variations impacted the movement of caravans, imposing a hiatus on long-distance com-

6 Veenhof 2008b; Barjamovic 20II.

7 Veenhof 2006 et 2008b; Michel 2008b.

8 Veenhof 2008b.

9 Michel 2008b, 372f., 380-384.

Io Kt ००/k Io:ii II-I8, kārum Ib, cf. Veenhof 2008a, I94-200.

II Forlanini 2006. 
mercial activity in winter, as the routes through the mountains became inaccessible due to snow and storms. In fact, allusions to interruptions in travel due to freezing temperatures and closed roads during the cold season are common in the surviving documentation. Even though forests covered much of the Anatolian plateau, merchants were forced to travel through desert-like areas during the dry season and therefore had to choose their itineraries based on sources of water and places where they could re-provision. The journey was divided into several stages, with breaks at inns, where people and animals alike could rest. Caravan accounts included fees for inns, totaling several shekels of silver or tin or several minas of copper; other expenses included fodder and rent for stables for the donkeys as well as lodging and food for the merchants. A salary was sometimes added for the guards. ${ }^{12}$ Thus, the regular passage of large caravans played an important role in local economies.

\subsection{The resources of the Anatolian states}

The Anatolian plateau was largely covered by forests, but a sizable portion of the region consisted of arable land and pastures. Farming and breeding livestock were the principle activities of the small Anatolian states. The past several years have seen an increase in archaeobotanical studies for various excavations of smaller sites in Anatolia, yet such studies are beginning for larger cities like Kültepe and Acemhöyük. Research carried out on the botanical remains at Kaman Kalehöyük, however, reveals the presence of no less than half a dozen varieties of grain. According to the textual evidence, the majority of non-irrigated fields were devoted to the cultivation of barley and wheat. The fields were alternately cultivated and allowed to lay fallow. ${ }^{\mathrm{I}}$ The many loan contracts that were made out to the Anatolians provide a good documentation of the ancient agricultural calendar. ${ }^{\mathrm{I}}$ Wheat was sown in autumn (erāšum, "to work" and "to sow"), barley in the spring. Once the grain had ripened (kubur uttitim, from July to October), the grain was harvested with sickles (sibit niggallim, eșādum "to harvest"), after which it was taken to the threshing floor (adrum). Finally, the grain was sold in sacks at the market, or stored in large jars in the palace warehouses. The Anatolians also cultivated sesame in order to make oil for food, perfume, and light.

In this period, land was owned either by farmers or by palace officials. Parts of the cultivated land were under the direct control of the palace itself. The urban population and the merchants of the kārum, meanwhile, lived on the surplus agricultural goods sold at the markets. ${ }^{15}$ This surplus also provided the funds for hiring men and animals for the caravans and paid for their re-provisioning at the roadside inns across the plateau. Certain fields

I2 Michel 2008b, 377, n. 25, text TC $3 \mathrm{I}_{5}$.

I3 Michel I997; Fairbairn 2006; Fairbairn et al. 2007; Dercksen 2008b.

I4 Michel I997; Dercksen 2008b; Veenhof 2008a, 234-245.

I5 Dercksen 2008a. 
were tied to the palace by a service obligation (tuzinnum) whereas other domains (ubādinnum) were given to high officials by the king. ${ }^{16}$ Landowners were required to give a portion of their harvests to the palace as a kind of tax. According to Yakar (I998), the communities that were established on the semi-arid plateau in the area around Kaniš had a largely selfsufficient agricultural economy. Nevertheless, the poorest farmers produced barely enough food for survival; they were often obliged to borrow grain in order to get by until the next harvest. They frequently mortgaged their lands against these debts.

Irrigated farmland was used by both the palace and individual landowners for the cultivation of fruit trees, vegetables, lentils, chickpeas, onions, leeks, aromatic plants, spices and animal fodder (in particular, vetch). ${ }^{17}$ Commoners also paid a fee for the use of irrigated water. ${ }^{18}$ Olive picking took place in autumn (serdum). To the north of Kanišs, grapes were also cultivated; the harvest took place in September (qitip kerānim).

Sheep and goat were allowed to graze the steppe and fallow fields. These herds were usually owned by the palace and were raised for meat, fat, milk, and wool. The sheep were plucked in the spring and the palace sold their wool in large quantities to the Assyrian merchants, who played the role of intermediaries in its trade; ${ }^{19}$ the wool produced at Mamma and Luhusaddia was particularly valued. ${ }^{20}$ The palace also raised mules, horses, oxen and dogs. ${ }^{2 I}$ Excavations of the kitchens at the palace of Açemhöyük have revealed the remains of sheep and goats, but also of oxen and pigs. ${ }^{22}$ Commoners, meanwhile, often raised a few sheep and pigs in their backyards. ${ }^{23}$

It was not, however, Anatolia's agricultural production that attracted the Assyrian merchants but rather its richness in minerals. ${ }^{24}$ The Anatolians possessed great quantities of copper, but they depended on Assyrian imports for the supply of tin, which was used to produce the highly valued bronze. The Assyrians, meanwhile, purchased gold and silver from the Anatolians to take home with them. Silver was extracted in the Taurus Mountains in the region to the south of Niğde; it was also imported from the west, and the city of Burušhattum was one of its major markets. Along with copper, silver was one of the principal forms of payment for small expenditures. One part of the silver acquired by the Assyrians was converted to gold at a rate of six to eight shekels of silver for one shekel of gold. The gold came from the west and southwest of Anatolia, as well as from the mountains to the northeast of Malatya.

\footnotetext{
Dercksen 2004b.

Michel 1997; Dercksen 2008b; Sturm 2008.

Kt o/k 52:IO-II, Albayrak 200I, 308. 3II.

Dercksen 2004a, I8I-190.

Michel 2006a; Michel - Veenhof 20I0; Lassen 2010.

Michel 2004; Dercksen 2008a; Kt g/t 35, cf. Balkan I957 and Michel 200I, no. 62.

Nicola - Glew I999.

Michel 1997; Michel 2006b.

Dercksen 2005 .
} 
Anatolia was a major producer of copper; the most heavily exploited mines could be found along the coast of the Black Sea and in the region of Ergani. ${ }^{25}$ Durhumit was the principal market for copper. ${ }^{26}$ Copper was a cheap metal, and it served as a currency for the purchase of common goods. When it was alloyed with the tin that was imported by the Assyrians it was used to manufacture bronze. The Assyrians purchased copper at Durhumit, refined it and traded it for silver at the markets in Burušhattum, Wahšušana and Kaniš. Bronze was used for the manufacture of tools, weapons, plateware and many other objects. ${ }^{27}$ Metallurgical workshops discovered at Kültepe contained many moulds for bronze tools, weapons and ingots. ${ }^{28}$

\section{The Anatolian states: organization and relations}

The textual record offers little information about the political structure, size, and economic importance of the different Anatolian centers. The rare allusions to the political sphere principally concern the Anatolian elite - for the most part, princes and palace officials involved in negotiations with the Assyrians. We can also glean information from the sources regarding events that interrupted trade activities, such as conflicts, rebellions, or the absence of the ruler. The latter could be either due to the king being on a journey or the throne being vacant. The growing number of publications of tablets from Kaniš in the last two decades has made it increasingly possible to reconstruct more and more fragments of Anatolian history. We must nevertheless recall that the surviving sources are primarily Assyrian and therefore only concern the regions within Anatolia that were visited by the Assyrian merchants.

\subsection{The zone of Assyrian activity in Asia Minor}

At the beginning of the second millennium BC, a dozen or so localities in central Anatolia underwent a process of rapid development: they were generally situated along the principal axes of circulation, and included Kültepe, Açemhöyük, Karahöyük Konya and Boğazköy. Built on the ruins of Early Bronze Age settlements, these sites were fortified and now included an upper part with a palace and temples - signalling the development of monumental architecture. The evolution of these cities seems to have been accompanied by profound political, economic and social changes. Indeed, it is at this moment that they - having pre-

25 Dercksen 1996.

26 Michel I99I.

27 Özgüç I986 and 2003; Dercksen 1996, 76-80; Sturm 200I; Michel 2008c.

28 Özgüç I986, 39-51; Müller-Karpe I994, 49-66. 
viously been nothing more than the capitals of very small territorial states - began to attract the interest of Assyrian merchants, who established themselves in kārum (or wabartum), located in the lower part of the cities. ${ }^{29}$

The sites in the heartland of the Anatolian plateau are the main sources for our knowledge of Anatolian chronology: they have furnished us with a highly precise stratigraphy as well as numerous texts, seals and seal impressions. The Assyrians chose the site at Kültepe as the center of their commercial operations in Asia Minor, which explains the more than I7,000 cuneiform texts discovered there over the last sixty years. Most of them were excavated in the lower city, which included living quarters for both Anatolian and Assyrian merchants, the central office of the kārum (bèt kārim, which has yet to be excavated), and a sanctuary for the god Aššur. The citadel site reveals I8 strata of human occupation, ranging from the Early Bronze Age to the Roman period (levels Io-6 correspond to the Middle Bronze Age); the lower city's stratigraphy only covers the Middle Bronze Age (IV-I). Levels IV and III, which date to the end of the third millennium BC and cover a considerable surface area, have not furnished us with any written sources. Level II, which corresponds to the principal phase of Assyrian settlement in the area, was used from the last decades of the 2oth century BC until I835 BC. Most of the archives that have been excavated thus far date to this period. The texts allow us to estimate that approximately 500 Assyrians lived in the lower city. The quarter partially burned down but it does not seem to have been abandoned, as level Ib shows signs of occupation two or three years after the end of level II. ${ }^{\circ}$ This second period of Assyrian inhabitation lasted until the end of the I8th century. Trade with Assyria slowed down during this period, and the written sources exhibit few different sign forms and spellings. ${ }^{\text {I }}$ The merchant quarters in Alişar (Amkuwa) and Boğazköy (Hattuš), which have each yielded less than one hundred tablets in excavations, are contemporaneous with the level Ib at Kaniš. ${ }^{22}$ Level Ia of Kaniš, meanwhile, corresponds to a phase of Assyrian withdrawal; no written documents have been unearthed from this period, although the discovery of ceramics imported from Syria testifies to the ongoing exchanges occurring at this time between Anatolia and Upper Mesopotamia.33

The trade documented in the detailed archives of the merchants at Kaniš dealt mostly with metals and textiles - neither of which has left much of a trace in the archaeological record. On the other hand, the rich findings of furniture discovered at Kaniš and other sites on the Anatolian plateau gives us an excellent idea of the material culture of the Bronze Age in the region. Ceramics, seals, and impressions of seals allow us to delimit the areas, in which the Assyrian merchants were active. This area can be specifically defined by the toponyms mentioned in the Assyrian archives. For example, to the Southwest, the site of Karahöyük

29 Yakar I998; Sagona - Zimanski 2009 .

30 Günbatt1 2008.

3 I Kryszat 2008a.

32 Dercksen 200 I.

33 Emre I995; Emre I999. 
Konya produced a considerable number of seal impressions showing that this site was part of the trade network that was initiated by the Assyrians. ${ }^{34}$ According to the texts, Burušhattum and Šaladuwar were the two most western cities in the Assyrian trade network. Burušhattum can no longer be identified with Açemhöyük,35 but Karahöyük Konya is a possible candidate for its modern location, although Barjamovic (2OII) situates it further to the west. Šaladuwar was probably situated to the northwest of the Salt Lake, perhaps in the bend formed by the Sakarya Nehri. Wahšušana and Nenašša were also located to the West of Kizllırmak. The cities of Ulama and Ušša, which were situated in the southern part of the plateau, also belonged to the trade network. To the north, the Assyrians traveled as far as Zalpa (Zalpuwa), close to the Black Sea. In the southeast, we assume that they never went further than Hahhum (Samsat), a city on the Euphrates, because the city of Karkemiš is not mentioned in the texts.

\subsection{The political organization of Anatolia}

At the beginning of the second millennium $\mathrm{BC}$, central Anatolia was divided into multiple political centers, ranging in size from small, fortified city-states to true territorial states with a capital and surrounding villages. The archives of Kaniš mention about 500 toponyms. Unfortunately, their importance remains obscure in most cases. The Assyrians doubtlessly took up residence in the largest and most economically developed of the cities. The economic resources of these states varied considerably depending upon their geographic location: certain regions played a crucial role in the silver trade (Burušhattum to the west), others in the copper trade (Durhumit to the north) and still others in wool (Mamma and Luhusaddia to the south).$^{36}$

The Assyrian terminology for Anatolian political entities is not at all precise. The term mātum, "country", logically refers to the territory of a city-state. But certain Assyrian marriage contracts make a distinction between ālum, "the City" (meaning Aššrur), and mātum, "the Country", which corresponds in this case to Central Anatolia. ${ }^{37}$ The archives dating to Level II of the kārum at Kaniš (Igth century BC) mention the territories of Burušhattum, Kaniš, Luhusaddia, Wahšušana and Zalpa to the north. The region situated along the interior of the Kizllirmak bend - the "Hattum" - contained several important cities, including Amkuwa, Hattuš, Tawinia, and Tuhpia. A marriage contract summarizing the area of activity for one Assyrian merchant references Kaniš, Burušhattum and the Hattum. ${ }^{8}$

34 Alp i968.

35 Dercksen 200I, 6of.; Miller 200I; Michel 2002.

36 Garelli I989; Michel I99I; Michel - Veenhof 20 Io.

37 ICK I 3.

38 Prag I 490. 
The Assyrians first established themselves in Kaniš, the capital of a territorial state, which became their administrative center for the entire period. There were about ten villages belonging to the kingdom of Kaniš (including Dadasun, Hailawakuwa, Meliliya, Talwahšušara, Tataša, Tiwara and Utiša ${ }^{39}$ ). Next, the Assyrians slowly settled the region between Upper Mesopotamia and Anatolia, and they created kārums in the cities of Eluhut, Nihria, Hahhum, Uršu, Southern Zalpa, Timilkia, Tegarama, and Šalahšuwa. Then they expanded their zone of activity towards the north (Hattuš, Šimala, Šinahutum, Tawinia, Tišmurna, Tuhpia, Durhumit, Šamuha), and to the west (Wahšušana and Šaladuwar) and towards the southwest (Nenašša, Burušhattum ${ }^{40}$ ). They also established themselves in about fifteen wabartums - a trading post under the authority of the nearest kārum - at Amkuwa, Hanaknak, Hurrama, Karahna, Kuburnat, Kuššara, Mamma, Šamuha, Šuppilulia, Ulama, Upē, Ušša, Wašhania, Northern Zalpa and Zimishuna. During the period of the kārum II, the Assyrians settled in more than forty localities.

In the next phase, which corresponds to level $\mathrm{Ib}$ of the kārum at Kaniš (I8th century $\mathrm{BC})$, some states increased in size and importance, while others disappeared entirely from the Assyrian zone of activity. Kaniš was among the largest with more than twenty villages in its territory, as recorded in a list of palace personnel discovered in the remains of the citadel.4I The kingdom of Mamma also seems to have had vassals, according to a letter sent by its king. $4^{2}$ Burušhattum in the west disappeared entirely from the documentation in this period, while Wahšušana became insignificant. The number of cities with an Assyrian merchant "colony" also diminished: the texts mention only ten kārums (Durhumit, Eluhhut, Kaniš, Kuburnat, Šaladuwar, Šuppilulia, Tawinia, Tegarama, Wahšušana and Wašhania) and five wabartums (Amkuwa, Hurrama?, Mamma, Šamuha, Timilkia?).

In spite of all this information, it is impossible to delineate the frontiers of the kingdom of Kaniš or its neighbors. The territory of Kaniš bordered to the southeast the territories of Luhusaddia, Hurrama, and Šalahšuwa. Contracts for the sale of slaves seem to suggest that the major political frontier was the Euphrates. 43

\subsection{The internal political organization of Anatolian states: the example of Kaniš}

Each city-state was ruled by a dynasty. The rulers were alternately called rubā'um, "prince", and rubātum, "princess", but were also often known just by a nisba ("Man of GN": Hattušaīum, Nenaššaīum, Wahšušanaīum, Timilkiaīum and Tipurziaīum). The Akkadian term

39 Forlanini 1992; Dercksen 2008b.

40 Veenhof 2008a, I64-I67.

4I Kt g/t 36 and Kt g/t 42 + Kt z/t II, Bilgiç I964; Günbattı I987; Forlanini I992, I75f.; Dercksen 2004b; Dercksen $2008 \mathrm{~b}$.

42 Balkan I957; Michel 200I, n. 62.

43 Hecker I997. 
šarrum "king" was used in the plural as šarrānum during the kārum Ib to designate petty kings, vassals of the princes of Mamma and Kaniš. The Sumerian equivalent, LUGAL, was used for the term rubā'um in the expression LUGAL GAL, meaning "Great Prince" (the equivalent of rubä'um rabi'um). Certain kingdoms were governed by a princely couple,44 others by a princess ruling alone. 45 In these latter cases, we are not certain whether the woman in question was a widow or the daughter of a ruler who died without a male heir.

In the kārum II period, we know of fifteen Anatolian states that were governed by a "prince": Amkuwa, Burušhattum, Durhumit, Hattuš, Hurrama, Kaniš, Kuburnat, Luhusaddia, Mamma, Nenašša, Šinahutum, Tawinia, Timilkia, Tuhpia, Wahšsušana, Wašhania. At Burušhattum, the local ruler was sometimes called "Great Prince", rubā'um rabi'um and must have had vassals.

Anatolian legal documents in the kārum Ib period give the name of a local ruler and of his rabi simmiltim (literally "chief of the stairs"), a title which sometimes corresponds to that of crown prince. Coming from Kaniš, these sources are primarily concerned with the local dynasty ${ }^{6}$ (see below). Princes are also referenced at other Anatolian sites - at Amkuwa, Kaniš, Luhusaddia, Mamma, Šalahšuwa and Tawinia - but we do not know their names.

The ruler exercised power from his palace. It was the center of the Anatolian administration and housed many hundreds of people, including high officials in charge of different sectors, workers, and artisans. The building called the "palace of Waršama", dating from layer Ib at Kaniš, occupied more than a hectare. 47 Old Assyrian sources dating to the level II period mention palaces at fifteen different locations; in the following period, only the palace at Šalahšuwa is mentioned. The fifty surviving titles we have for Anatolian officials (generally constructed on the principle of rabi+substantive) suggest a sophisticated administration that oversaw every sector of the palace economy. However, we know little about the activities of individual officials. $4^{8}$ The known titles are Assyrian translations of Anatolian terms, and they sometimes cause confusion. At the top of the hierarchy was the rabi simmiltim; below him were the rabi sikkatim, who had commercial and military responsibilities (he supervised the "chief of the troops", rabi ummanātim), and the rabi huršātim, "chief of warehouses", who was in charge of the palace storage units. The responsibilities of the "second man", the šinahilum, are unclear, as are those of the "steward" (alahhinnum), especially as it appears to be possible for one person to hold both offices. These two terms, borrowed from Hurrian, are attested in other Akkadian texts;49 they also appear in the abstract form in the Old Assyrian corpus (alahhinnuttum, šinahiluttum).50 The "majordomo", rabi bêtim,

44 KTK io6; Kt 93/k I45.

45 Kaniš: Michel 200I, n. 207; Luhusaddiya: Michel 200I, n. IO; Wahšušana: KTS I 50c; Alişar: OIP 275.

46 Veenhof 2008a, I69-I73.

47 Özgüç 2003, I87-I92.

48 Veenhof 2008a, 219-245.

49 Dercksen 2007, 37 f.

50 Veenhof I989, 5I8. 
supervised the palace domain, while the "chief of the gates", rabi abullattim, along with the "chief of the porters", rabi ütu'e, oversaw the palace entrances, undoubtedly assisted by the guards under the authority of the "chief of the guards", rabi massarātim.

Among the prince's intimates were the "chief scepter-bearer", rabi hattim, the "chief cup-bearer", rabi šāqe, and the "chief of the tables" rabi paššūrē. The prince's private staff perhaps also included the "chief vizier", rabi šukkallim, the "chief of the heralds", rabi nāgirē, the "chief of the messengers", rabi lāsimē, and the "chief of the interpreters", rabi targumanne.

The "men", awilè, the "workers", șābe, and the "slaves", urdēe, were overseen by three different officials. The artisans, under the overall direction of the "chief of the workers", rabi șābē/șābim, were further separated into different trades, each supervised by another chief, such as the "chief of the metalworkers", rabi nappāhē, who worked closely with the "chief of the arms", rabi kakkē, himself answerable to the rabi sikkatim. In the agricultural sector, we find the "chief of the barley", rabi še'e, the "chief of the threshing floor", rabi adrim, the "chief of the gardens", rabi kiriātim, and the "chief of the gardeners", rabi

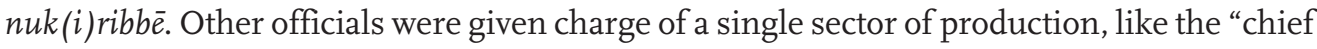
of the vegetables", rabi ürqē, "the chief of the wine", rabi kirānim, the "chief of the flax", rabi kittātim, and the "chief of the oil", rabi šamnim, who was charged with collecting (sesame?) oil and distributing it throughout the palace. The "chief of the wood", rabi esse, was probably responsible for supplying the palace and its kitchens with firewood. The officials who oversaw the palace flocks were given titles reflecting the animals they were charged with supervising: the "chief of the horses", rabi sisē, the "chief of the mules", rabi perdim, the "chief of the dogs", rabi kalbātim. One Peruwa, apparently "chief of the shepherds", rabi rē'éere'im, whose records were unearthed during the earliest excavations at Kültepe, accumulated enough wealth to purchase an entire village. The goods produced by the palace lands were doubtlessly sold under the authority of the "chief of the market", rabi mahirim. In the religious domain, finally, the prince had at his disposition the "chief of the oblates", rabi šariqe $\bar{e}$, and the "chief of offerings", rabi niqee. The palaces of Anatolia were clearly economic centers, and had many dealings with foreign merchants.

Aside from palace officials and artisans the Anatolian population was essentially rural, free but poor (hupšum). The farmers cultivated just enough to support the needs of their family, and the majority of the land belonged to the urban elite and to the palace. The prince often bestowed land or even entire villages on palace officials, either as gifts that they were then free to resell, or as compensation for services rendered. The service due to the king or to a high official - called arhālum, and mentioned only in the archives at Kaniš - was required only if someone lived in the "household of the king"; if the person left the household (because of a divorce, for example), he became exempt from service. ${ }^{\text {I }}$ Among the kinds of service that counted for the arhālum was the corvée (unušsum), principally docu- 
mented during the kārum Ib and whose name, Hurrian in origin, also appears in the second half of the second millennium at Alalakh IV and at Ugarit (as bēlū unuššim). ${ }^{5^{2}}$ In one surviving trade agreement, the ruler of Kaniš promises not to disturb the Assyrians while taking a census of the people bound to the unuššm service. ${ }^{53}$

It was not unusual that individuals entered into slavery in order to pay off a debt, either sold by a relative or by themselves; they could buy their freedom back after a certain amount of time had passed. The amount of time that had to pass was agreed upon when the person was sold into debt slavery, and usually they had to pay at least double the price of their original debt. The sale of Anatolian slaves was supervised by the reigning prince or by one of his representatives.

The texts offer little information on the priesthood, and we have no understanding of the organization of the temples. The only temples mentioned are those to Anna and Nipas. The patron deity of Kaniš seems to have been Anna (ilat älim) and the texts give other names to the deities revered by the inhabitants of the city-state: Hikiša, Ilalianta, Kubabat, the Lord of the Battle (Bēl qablim), Nisaba (Halki), Pirwa, the storm god, and the sun god. We also know the names of a certain number of priests, either because they appear in commercial transactions, or because they were landowners, but we know nothing of their activities in the religious cult. 54

\subsection{Foundations for a political history of Anatolia}

Giving a continuous account of the political history of Anatolia during the kārum periods would be impossible at this stage; in fact, the information given by the Assyrian archives on local political events is brief and undated. During the level II at Kaniš (ca. I950-I835 BC), the Anatolian city-states, whether powerful or weak, were sometimes allies and sometimes rivals; their urban centers were all fortified, suggesting repeated conflict. Each city-state secured trade agreements with the Assyrians independently of the others. 55 The absence of a strong central power in Anatolia undoubtedly helped the commercial activities of the Assyrians, whose business in turn guaranteed a certain degree of intra-Anatolian stability by unifying the local trade in copper and wool. The peace guaranteed by the commercial treaties reflected an ideal situation, not necessarily the reality: the correspondence of merchants testifies to various internal political problems, including unrest following the death of a prince, rebellions of various kinds, and the forming of coalitions and conflicts between the Anatolian states..$^{6} \mathrm{~A}$ vacant throne or political instability within a city-state often

52 von Dassow 2008, $162 \mathrm{f}$.

53 Kt ००/k 6:84, Günbatt1 2004; Veenhof 2008a, I93.

54 Kryszat 2006.

55 Veenhof, in print.

56 Michel 2008a; Michel 2008b. 
brought caravan traffic to a halt, or even caused the city to be closed to foreigners. ${ }^{57}$ The absence of a local sovereign during a military expedition could plunge the state into anarchy; ${ }^{8}$ similarly, the belligerent behavior of a ruler could disrupt trade in the region: "the king has shed blood and his throne is no longer secure. The treaties are postponed. The princes are watching one another." 59 Certain texts refer to the oaths (mamitum) sworn by different sovereigns so as to form an alliance, like that between Wahšušana and Kaniš; ${ }^{60}$ but the references to conflicts between Anatolian states are more frequent, as Assyrian merchants were sometimes unwillingly involved. Aššur-taklāku, whose archives were excavated in I993, seems to have been taken hostage in the war between Tawinia and Wašhania. ${ }^{6 \text { I }}$ The movements of kings are also mentioned in the archives whenever they cause the caravan routes to be closed to commercial traffic; ${ }^{62}$ these royal journeys reflected diplomatic relations between certain Anatolian princes.

The period of the kārum II was marked by an ongoing war to the west between the cities of Burušhattum and Wahšušana, a conflict in which Šaladuwar was involved several times: "Invade the land of Wahšušana! Otherwise, I am your enemy." ${ }_{3}$ And again: "until the rabi sikkatim makes the princes of Burušhattum, Ušunalam, and Wahšušana swear an oath, he must not visit (these places)". ${ }^{64}$ The battle turned in favor of the city-state of Burušhattum, the main market for silver, which took on importance at the end of the kārum II, during which the Assyrian community abandoned the city of Wahšušana. ${ }^{65}$ In the same period (or perhaps at the beginning of the kārum Ib), the princes of Šinahutum, Amkuwa and Kapitra joined in an alliance against the king of Hattuš. ${ }^{66}$

The information at our disposal for the period of the kārum Ib in Kaniš (ca. I830-I700) changes as the sources are of lesser quality and of a very different nature. References to relations between the principalities become rarer, and the majority of references to the local princes themselves come from Anatolian contracts notorized by the local sovereign and by the rabi simmiltim; kārum Ib has also yielded several trade agreements. Hurmeli?, Harpatiwa, Inar and his son Warša/uma, Pithana and his son Anitta, and Zuzzu succeeded to the throne of Kaniš during the I8th century BC. ${ }^{67}$ In a letter addressed to Waršama, prince of Kaniš, Anum-hirbe, Hurrian prince of Mamma, recounts the invasion of his kingdom and the plundering of his villages by a vassal of the ruler of Kaniš; he also refers to the long

57 Kt 93/k I79 and 237; Michel 2008a.

58 Kt 92/k 526; Veenhof, in print.

59 Michel 200I, no. 98 et 99.

60 Michel 200I, no. 65.

6I Michel - Garelli I996; Günbattı 200I; Michel 2008a.

62 Kt 93/k 685, 7-I8; see also Kt 92/k I94.

63 Michel 200I, no. 57 .

64 Michel 200I, no. Ioo and also no. 64.

65 Barjamovic et al. 2012; Veenhof, in print.

66 KTK Io, Larsen I972; Michel 200I, no. 63.

67 Veenhof 2008a, I69-I73; Kryszat 2008b; Kryszat 2008c; Barjamovic et al. 2012. 
siege of Harsamna carried out by his father, Inar. ${ }^{68}$ The same conflict may have been referenced in an unpublished letter sent to the kārum at Kaniš by the assembly of Aššur: it gives an account of a war between Harsamna and Zalpa, just after the death of Šamšì -Adad and the ascension of Išme-Dagan to the throne. ${ }^{69}$ The reigns of Pithana and Anitta are documented by the Anitta text, a later Hittite document, which recounts how Pithana, king of Kuššara, conquered Kaniš and dethroned its king..$^{\circ 0}$ Anitta succeeded his father to the throne of Kaniš and enjoyed great success on the battlefield: he bestowed upon himself the title of Great Prince (rubā'um rabium). He destroyed Hattuš around $173^{7 \mathrm{TI}}$ and occupied the palace of Waršama, which he had not destroyed. As the new king of Kaniš he ordered the construction of two temples. Zuzu, king of Alahzina, the latest of the conquerors of Kaniš, is the last known ruler (Great Prince) of Kaniš; he probably reigned from about I725 until the last years of the I8th century..$^{2}$ The rivalries between Anatolian states seem to have been the cause of the end of the kārum Ib: several kingdoms disappeared entirely and are no longer documented during the Hittite period.

\section{The population of the trading posts in Anatolia}

The main motivation for the presence of the Assyrians in Asia Minor was above all related to trade and was based on the treaties ratified by local authorities; other merchants, coming from Syria and Upper Mesopotamia, also frequented the Anatolian trading posts. At Kaniš, the relations between foreign merchants (especially Assyrian) and the Anatolians went beyond just the exchange of trade-goods; interactions between the two communities are visible in the material culture, the language and the writing. Mixed marriages became common and a hybrid society developed within the lower city.73

\subsection{The Assyrians}

The Assyrians living in the lower city quarters were administratively and legally independent from the local authorities. Yet they were connected to the government of Aššur via the $k \bar{a} r u m$ at Kaniš. Interactions with local authorities were determined by the treaties signed by the representatives of the kârum and the local prince; these agreements recognized the mutual and complementary interests of the two parties and guaranteed peaceful coexist-

68 Balkan I957; Miller 200I.

69 Günbatt1 2005 .

70 Waršama, ca. I750; Carruba 2003; Barjamovic et al. 2012.

7I Kryszat 2008c.

$72 \mathrm{Kt} \mathrm{j/k} 625$ and Kt 89/k 625; ca. I7I6 according to Barjamovic et al. 2012.

73 Michel 2010. 
ence between them. The Anatolian palace collected an import duty on merchandise and had preemptive purchasing rights to textiles; in exchange, the Assyrians were permitted to reside within the kārum and were accorded certain protections. Similarly, their caravans, men, animals and merchandise were protected along guarded routes. 74 The first Assyrians to settle at Kaniš, usually the eldest sons of trading families, came to Anatolia to represent their family firms. They did not necessarily come from the wealthiest classes of Aššur, but, being generally richer than the indigenous population, they quickly became the major creditors in Anatolia. Many of them had houses in the kārum; others lived temporarily in the homes of other Assyrians, sometimes leaving their archives there.75

Two treaties dating from the kārum Ib have been discovered at Kaniš in recent years: one was negotiated with the Great Prince of Kaniš (either Anitta or Zuzu) and the other with dignitaries from Hahhum. $7^{6}$ They guaranteed that caravan traffic would continue even during times of conflict, and depict a situation slightly different from that of the kārum II. The texts thenceforth distinguish Assyrians who resided in the kārum (wašbutum) from those involved in the caravan trade with Aššur (āliküšša harrān ālim). ${ }^{77}$ The former, who were completely invested in intra-Anatolian trade, seem to have been less prosperous, and often in debt. Individual clauses in the treaties therefore protected Assyrian households with tamkārum or widows from seizure of property by Kanišites, hapīrū, or the local prince..$^{8}$

\subsection{The "Anatolians"}

In the lower city, the Assyrians dealt with many different ethnic groups whom they invariably designated with the generic term nu'a'um, meaning "Anatolian". For the Assyrians, this term was not pejorative; the Anatolians, meanwhile, designated the Assyrians by the word tamkārum, which signifies "the merchant".79 The Anatolians in Kaniš lived either in the citadel or in the lower city; those who lived in the latter were often merchants. Many of them bore personal names with either a Hittite or Luwian etymology; certain others had names of Hattic origin - an agglutinative language which does not belong to any known linguistic family but which seems to have been influenced by Luwian. ${ }^{80}$ The Hittites and Luwians, both Indo-European populations, seem to have arrived in central Anatolia during the last centuries of the third millennium. Hittite became the dominant language in central

74 Michel 200I, no. 87; Veenhof 2003.

75 Michel - Garelli I997, 27-34.

76 Günbatt1 2004; Veenhof 2008a, I83-218.

77 Barjamovic et al. 2012.

78 Veenhof 2008a, I47-I82.

79 Michel 2010.

80 Garelli i963, I27-I68; Dercksen 2002; Goedegebuure 2008. 
Anatolia from about the igth century forward; the majority of linguistic borrowings discovered in the Old Assyrian archives are taken from an early form of Hittite. ${ }^{8 \mathrm{I}}$

The archives discovered in certain houses in the kārum in Kaniš show a concentration of houses belonging to the Assyrians in the north and more houses belonging to the Anatolians in the south, but the separation between the communities was not so clear. Assyrians and Anatolians interacted on a daily basis and the use of different languages does not seem to have been an obstacle to communication, a fact confirmed by the numerous "native" words to be found in Old Assyrian texts. The interpreters (targumannum) were not numerous and seem to have been principally employed by the government administration to maintain commercial and diplomatic relations between local palaces and the kārum offices. It is possible that these translators may have offered their services to other foreign merchants doing business in Kaniš.

\subsection{The Hurrians and other foreigners in Anatolia}

The archives taken from Kaniš mention other groups of foreigners, designated by the languages they speak: certain personal names have an Amorite or Hurrian etymology, and certain individuals are identified as natives of foreign places, such as Ebla, indicating that there were close commercial contacts between the Anatolian plateau and northern Syria. ${ }^{82}$ The laws of the city of Aššur prohibited Assyrians from selling gold to the different groups they traded with at Aššrur (except to the Elamites) or on the road to Asia Minor, including the Akkadians (meaning Babylonians) to the south of Aššur with whom they traded goods; the Amorites, whose territories they crossed where the Euphrates curves to the west, at the Upper Jazirah (where the village of Nihriya, among others, is located); and the Subareans (or Hurrians), who lived to the north of Aššrur along the Tigris and in the mountains of Upper Mesopotamia. ${ }^{8}$ The gods of Amurru and Subartu are invoked in a treaty ratified between Aššrur and Apum. ${ }^{84}$

During kârum Ib period (I8th century), the Hurrians, who several centuries later would found the kingdom of Mittani, progressively settled west of the Euphrates, south of the Anti-Taurus, and east of Anatolia. ${ }^{85}$ Although tablets dating from the kārum II at Kaniš contain words of Hurrian origin ${ }^{86}$ as well as cloth produced in Hurrian territory or woven in the Hurrian style, ${ }^{87}$ the majority of Hurrian personal names mentioned in the Old Assyrian

8I Dercksen 2007.

82 Bilgiç I992; TPAK I I09:4; Kt 88/k 525:5-6, cf. Michel 20ıоb; Kt 9I/k 338:2; Kt 94/k 42I:28.

83 Michel 200I, no. 2.

84 Eidem I99I; Kryszat 2003.

85 Veenhof 2008c; Wilhelm 2008; Michel 2012.

86 Dercksen 2007.

87 Michel - Veenhof 20I0; Michel 2012. 
archives appear in texts dating from the kärum Ib. This is the case, for example, with two letters addressed to a Hurrian named Unapše, who had temporarily or definitively settled in Kaniš. ${ }^{88}$ In the first of these letters, Ehli-Addu, writing from western Syria, reclaims the reimbursement of a debt left unpaid for two decades; he mentions witnesses in the city of Haššum, quite certainly located in the region of Gaziantep. ${ }^{8}$ In the second letter, Abduata asks Unapše to send a tablet containing a proposition about a sale of textiles to a scribe who understands and reads Hurrian..$^{\circ}$ In both cases, these letters have no connection to other documents in the archive. Two other documents excavated in I990 contain foreign names, mostly Hurrian. The arbitration Kt 90/k 358+359, dating presumably to the kārum Ib period and concerning commercial affairs that took place in part at Burušhattum, involved one Urumum and the Hurrian Dakip-šarri. ${ }^{\text {I }}$ The letter Kt 90/k 360 was addressed to five persons bearing Amorite and Hurrian names: G/Kalali, whose official title, halșuhlu, was Hurrian, the Amorite Zimrī-Addu, or Hašip-Teššup, a Hurrian personal name that is mentioned in the archives of Shemshara, and later in those of Nuzi. $9^{2}$ The foreign syllabary and composition of this letter, which recalls festive days spent by the author in the company of the ruler of Kaniš, suggests that it was sent from somewhere along the Upper Tigris or east of the river. These various documents indicate that during the kārum Ib, new populations took an interest in trade with Anatolia. Finally, the best known Hurrian, who moved into Anatolia in the I8th century BC, is the ruler of Mamma, Anum-hirbe, who was the author of a letter sent to his counterpart at Kaniš. 93

\subsection{Relations between different ethnic groups}

At Kanišs, the Assyrians settled in the lower city; they purchased houses built in the local style and used the pottery produced by local craftspeople for their everyday needs. Nevertheless, certain traces bear witness to their foreign origins.94 Artifacts discovered in their tombs and houses indicate cultural practices that were typical for the Assyrians. Although they were immersed in a cultural and linguistic environment that was very different from their own, the Assyrians adapted their vocabulary to the local realities. The Old Assyrian tablets include numerous loandwords, not only from an early version of Hittite spoken at Kaniš, but also from Hurrian.95 Unfortunately, the documentation is very vague when it

88 AKT 4 34:23.

$89 \mathrm{Kt} \mathrm{k/k} \mathrm{4,} \mathrm{Hecker} \mathrm{I99I} \mathrm{and} \mathrm{I996;} \mathrm{Wilhelm} 2008$.

90 Subarean; Kt 9I/k 539, Veenhof 2008c.

9I Michel 20Iob.

92 Michel 20ıob.

93 Balkan I957; Miller 200I.

94 Michel 20ioa.

95 Dercksen 2007. 
comes to information on the integration of other foreigners into the culture of the lower city at Kaniš; for example, written documents mentioning the Hurrians, whose presence is particularly well attested during the kārum Ib, are still too few to allow for any major conclusions.

The Anatolians, meanwhile, adopted the system of syllabic writing used by the Assyrians but did not attempt to apply it to their own language; they preserved the Old Assyrian dialect, which had become the language of diplomacy. It is well known that Anatolian scribes in the major urban centers wrote contracts that contained certain grammatical errors, for example, confusing grammatical genders, clearly indicating the different linguistic environments..$^{6}$ Furthermore, some of the houses, in which archives were found, belonged to indigenous Anatolians. The Anatolians, who traditionally used stamp seals, began using the cylinder seal under the influence of the Assyrians and developed a local style that borrowed elements from Old Babylonian, Old Assyrian and Old Syrian styles, all of which had arrived through trade. 97

At first the Anatolians acted as clients of the Assyrians: they purchased Assyrian merchandise, paid directly or with credit, and those who did not belong to the elite often appeared in the records as debtors to the Assyrians, owing small sums of silver, copper, or sacks of grain. Some Anatolians, however, entered into real trade partnerships with the Assyrians: they were entrusted with merchandise, lending capital and selling slaves. During their lengthy residency in Anatolia, certain Assyrians, already married at Aššur, got married for a second time to Anatolian women. $9^{8}$ Others settled in Kaniš with their families; Assyrian widows took Anatolian men as second husbands. The Assyrian population of Kaniš decreased perceptibly during the second half of the I8th century (at the end of the kārum II); nevertheless, long-distance trade continued with Aššur. According to the royal archives at Mari, in the I8th century BC (during the kārum Ib), great trade caravans still traveled between Aššur and Kaniš, and this trade remained profitable both for investors in Aššur and Assyrians in Kaniš, who had accounts at the local trading post. Many Assyrian merchants gradually climbed upwards on the social scale, while other Assyrian merchants got more and more involved in the local trade in copper and wool, lost contact with their countrymen in Aššur, and at times became impoverished. Specific clauses included in the treaties dating from the kārum Ib make some attempts at protecting these Assyrians, who were cut-off from their homeland and increasingly immersed in a hybrid Assyrio-Anatolian community. 99

96 Dercksen 2007; Kryszat 2008a.

97 Özgüç I965; Özgüç 2006.

98 Michel 2008d.

99 Michel 20ıо; Barjamovic et al. 2012. 
The Old Assyrian archives excavated at Kaniš, Amkuwa and Hattuš allow us to reconstruct some aspects of the political, economic and social history of Anatolia in the first centuries of the second millennium BC. The presence of the Assyrians in Central Anatolia was primarily economic and not political. They were the most numerous and best organized foreigners in the Anatolian trading posts, especially at Kaniš, where they did business with other merchants from southwestern Turkey, from northern Syria and from Upper Mesopotamia. Among the Upper Mesopotamians, individuals bearing Hurrian names, although rare during the kārum II, seem to have become well established in eastern Anatolia during the kārum Ib. Their arrival in Anatolia from Upper Mesopotamia, where certain Hurrian rulers reigned (in, for example, the state of Idamaras ${ }^{100}$ ), seems to have coincided with the reign of Šamš̀i-Adad. ${ }^{\text {Ior }}$ Letters found at Kanišs, most probably dating to the kārum $\mathrm{Ib}$, which contain an unusual syllabary as well as Hurrian expressions and personal names, show the increasing interest the Hurrians had for Anatolia, where certain Hurrian speakers had taken power. ${ }^{\mathrm{IO2}}$ In any case, the documentation of the Hurrian presence in Anatolia in the I8th century BC remains limited: only $2 \%$ of the discovered documents at Kaniš date from the kārum Ib period, and they are for the most part still unpublished. Finally, with the departure of the Assyrians involved in long distance trade at the end of the I8th century, writing disappeared from Anatolia for nearly a century, during which time the Hurrian presence must have slowly taken on a more substantial and structured form. ${ }^{\text {IO3 }}$

\title{
Bibliography
}

\begin{abstract}
Albayrak 200I
İ. Albayrak, Kültepe Metinlerinde Geçen mā'û "Su” Kelimesi, Anadolu Medeniyetleri Müzesi 2000 Yıllığı (Ankara 200I) 300-3II.
\end{abstract}

Alp 1968

S. Alp, Zylinder und Stempelsiegel aus Karahöyük bei Konya, TTKY V/26 (Ankara I968).

Balkan 1957

K. Balkan, Letter of King Anum-Hirbi of Mama to King Warshama of Kanish, TTKY VII/3Ia (Ankara I957).

Barjamovic 20II

G. Barjamovic, A Historical Geography of Ancient Anatolia in the Old Assyrian Colony Period, CNIP 38 (Copenhagen 20II).

I00 Cf. Guichard (this volume, p. I47-I60).

IoI Cf. J. Eidem (this volume (p. I37-I46).

IO2 Anum-hirbe at Mamma, for example; Miller 200I.

I03 Cf. de Martino (this volume p. 6I-74). 


\section{Barjamovic et al. 2012}

G. Barjamovic - Th. Hertel - M. T. Larsen, Ups and Downs at Kanesh - Chronology, History and Society in the Old Assyrian Period, OAAS 5, PIHANS I20 (Leiden 20I2).

Bilgiç 1964

E. Bilgiç, Three Tablets from the City Mound of Kültepe, Anatolia 8, I964, I45-163.

\section{Bilgiç 1992}

E. Bilgiç, "Ebla" in Cappadocian Inscriptions, in: H. Otten et al. (eds.), Hittite and Other Anatolian and Near Eastern Studies in Honour of Sedat Alp (Ankara I992) 6I-66.

\section{von Dassow 2008}

E. von Dassow, State and Society in the Late Bronze Age Alalah under the Mittani Empire, SCCNH I7 (Bethesda 2008).

\section{Dercksen 1996}

J. G. Dercksen, The Old Assyrian Copper Trade in Anatolia, PIHANS 75 (Istanbul I996).

\section{Dercksen 200I}

J. G. Dercksen, 'When we met in Hattuš'. Trade according to Old Assyrian Texts from Alishar and Boğazköy, in: Wilfred H. van Soldt et al. (eds.), K. R. Veenhof Anniversary Volume, PIHANS 89 (Leiden 200I) 39-66.

\section{Dercksen 2002}

J. G. Dercksen, Kultureller und wirtschaftlicher Austausch zwischen Assyrern und Anatoliern (Anfang des zweiten Jahrtausends v. Chr.), in: B. Harmut et al. (eds.), Brückenland Anatolien? Ursachen, Extensität und Modi des Kulturaustausches zwischen Anatolien und seinen Nachbarn (Tübingen 2002) 35-43.

\section{Dercksen 2004a}

J. G. Dercksen, Old Assyrian Institutions, MOS Studies 4, PIHANS 98 (Leiden 2004).

\section{Dercksen 2004b}

J. G. Dercksen, Some Elements of Old Anatolian Society in Kanis, in: J. G. Dercksen (ed.), Assyria and Beyond. Studies Presented to Mogens Trolle Larsen, PIHANS Ioo (Leiden 2004) I37-I78.

\section{Dercksen 2005}

J. G. Dercksen, Metals According to Documents from Kültepe-Kanish Dating to the Old Assyrian Colony Period, in: Ü.Yalcun (ed.), Anatolian Metal III. Der Anschnitt, Beiheft I8 (Bochum 2005) I7-34.

\section{Dercksen 2007}

J. G. Dercksen, On Anatolian Loanwords in Akkadian Texts from Kültepe, ZA 97, 2007, $26-46$.

\section{Dercksen 2008a}

J. G. Dercksen, Subsistence, Surplus and the Market for Grain and Meat at Ancient Kanesh, AoF 35, 86-IO2. 


\section{Dercksen $2008 b$}

J. G. Dercksen, Observations on Land Use and Agriculture in Kaneš, in: C. Michel (ed.), Old Assyrian Studies in Memory of Paul Garelli, OAAS 4, PIHANS II2 (Leiden 2008) I39-I57.

\section{Dönmez - Beyazıt 2008}

Ş. Dönmez - A. Y. Beyazit, A General Look at the Central Black Sea Region during the Middle Bronze Age and a New Approach to the Zalpa Problem in the Light of New Evidence, in: J. G. Dercksen (ed.), Anatolia and the Jazira during the Old Assyrian Period, OAAS 3, PIHANS III (Leiden 2008) IOI-I35.

\section{Eidem I99I}

J. Eidem, An Old Assyrian Treaty from Tell Leilan, in: D. Charpin - F. Joannès (eds.), Marchands, diplomates et empereurs. Études sur la civilisation mésopotamienne offertes à Paul Garelli (Paris I99I) I85-207.

\section{Eidem 20II}

J. Eidem, The Royal Archives from Tell Leilan. Old Babylonian Letters and Treaties from the Lower Town Palace East, PIHANS II7 (Leiden 20II).

\section{Emre 1995}

K. Emre, Pilgrim-Flasks from Level I of the Kārum of Kaniş, BMECCJ 8, I995, I73-200.

\section{Emre 1999}

K. Emre, Syrian Bottles from the Kārum of Kaniş, BMECCJ II, I999, 39-50.

\section{Fairbairn 2006}

A. S. Fairbairn, Archaeobotany at Kaman Kalehöyük 2005, Kaman-Kalehöyük 15, 2006, I33-I38.

\section{Fairbairn 2007}

A. S. Fairbairn - C. Longford - B. Griffin, Archaeobotany at Kaman Kalehöyük (2006), Kaman-Kalehöyük I6, 2007, I5I-I58.

\section{Forlanini 1992}

M. Forlanini, Am Mittleren Kizllırmak, in: H. Otten et al. (eds.), Hittite and Other Anatolian and Near Eastern Studies in Honour of Sedat Alp (Ankara I992) I7I-I79.

\section{Forlanini 2006}

M. Forlanini, Étapes et itinéraires en Aššur et l'Anatolie des marchands paléo-assyriens: nouveaux documents et nouveaux problèmes, Kaskal 3, 2006, I47-I76.

\section{Garelli 1963}

P. Garelli, Les Assyriens en Cappadoce, Bibliothèque archéologique et historique de l'Institut français d'archéologie d'Istanbul ig (Paris I963).

\section{Garelli 1989}

P. Garelli, Le marché de Burušhattum, in: K. Emre et al. (eds.), Anatolia and the Ancient Near East. Studies in Honour of Tahsin Özgüç (Ankara I989) I49-I52.

\section{Günbattı 1987}

C. Günbatt1, Yeniden İşlenen Bir Kültepe Tableti (Kt g/t 42+z/t II), Belleten 5I, I987, I-IO. 


\section{Günbattı 200I}

C. Günbatt, The River Ordeal in Ancient Anatolia, in: W. H. van Soldt et al. (eds.), K. R. Veenhof Anniversary Volume, PIHANS 89 (Leiden 200I) I5I-I60.

\section{Günbattı 2004}

C. Günbatt1, Two Treaty Texts Found at Kültepe, in: J. G. Dercksen (ed.), Assyria and Beyond. Studies Presented to Mogens Trolle Larsen, PIHANS Ioo (Leiden 2004) 249-268.

\section{Günbattı 2005}

C. Günbatt1, 2000 ve 200I Y1lı Kültepe Kazılarında Ele Geçen Bazı I-b Tabletleri, 5.UHKB, Çorum 2002 (Ankara 2005) 445-45I.

\section{Günbattı 2008}

C. Günbatt1, An Eponym List (KEL G) from Kültepe, AoF 35, 2008, I03-I32.

\section{Hecker 199I}

K. Hecker, Zur Herkunft der Hethitischen Keilschrift, in: S. Alp (ed.), Uluslararas1 I. Hititoloji Kongresi Bildirileri (I9-2I Temmuz I990, Çorum) (Ankara I99I) 53-63.

\section{Hecker 1996}

K. Hecker, Zur Herkunft der Hethitischen Keilschrift, in: D. I. Owen - G. Wilhelm (eds.), Nuzi and the Hurrians. Richard F. S. Starr Memorial Volume, SCCNH 8 (Bethesda I996) 29I-303.

\section{Hecker 1997}

K. Hecker, Über den Euphrat (Ortsbezogene Restriktionen in aA Kaufurkunden), ArchAn. 3, I997, I57-I72.

\section{Kryszat 2003}

G. Kryszat, Zur Liste des Schwurgötter im Assur-Apûm-Vertrag, Isimu 6, 2003, 99-I02.

\section{Kryszat 2006}

G. Kryszat, Herrscher, Herrschaft und Kulttradition in Anatolien nach den Quellen aus den altassyrischen Handelskolonien. Teil 2: Götter, Priester und Feste Anatoliens, AoF 33, 2006, IO2-I24.

\section{Kryszat 2008a}

G. Kryszat, The Use of Writing among the Anatolians, in: J. G. Dercksen (ed.), Anatolia and the Jazira during the Old Assyrian Period, OAAS 3, PIHANS III (Leiden 2008) 23I-238.

\section{Kryszat 2008b}

G. Kryszat, Herrscher, Kult und Kulttradition in Anatolien nach den Quellen aus den altassyrischen Handelskolonien. Teil 3/I: Grundlagen für eine neue Rekonstruktion der Geschichte Anatoliens und der assyrischen Handelskolonien in spätaltassyrischer Zeit, AfO 35, 2008, I56-I89.

\section{Kryszat 2008c}

G. Kryszat, Herrscher, Kult und Kulttradition in Anatolien nach den Quellen aus den altassyrischen Handelskolonien. Teil 3/2: Grundlagen für eine neue Rekonstruktion der Geschichte Anatoliens und der assyrischen Handelskolonien in spätaltassyrischer Zeit II, AfO 35, 2008, 195-219. 


\section{Larsen 1972}

M. T. Larsen, A Revolt against Hattuša, JCS 24, I972, Ioof.

\section{Larsen 2002}

M. T. Larsen, The Aššur-nādā Archive, Old Assyrian Archives I, PIHANS 96 (Leiden 2002).

\section{Lassen 2010}

A.W. Lassen, The Trade in Wool in Old Assyrian Anatolia, JEOL 42, 2010, I59-I79.

\section{Marro 2004}

C. Marro, Upper-Mesopotamia and the Caucasus: Essay on the Evolution of Routes and Road Networks from the Old Assyrian Kingdom to the Ottoman Empire, in: A. Sagona (ed.), A View from the Highlands. Studies in Honour of Charles Burney (Leiden 2004) 9I-I2O.

\section{Michel I99I}

C. Michel, Durhumid, son commerce et ses marchands, in: D. Charpin - F. Joannès (eds.), Marchands, Diplomates et Empereurs, Etudes sur la civilisation mésopotamienne offertes à Paul Garelli (Paris I99I) 253-273.

\section{Michel 1997}

C. Michel, À table avec les marchands paléo-assyriens, in: H. Waetzoldt - H. Hauptmann (eds.), Assyrien im Wandel der Zeiten, CRRAI 39, HSAO 6 (Heidelberg I997) 95-II3.

\section{Michel 200I}

C. Michel, Correspondance des marchands de Kaniš au début du II millénaire av. J.-C., LAPO I9 (Paris 200I).

\section{Michel 2002}

C. Michel, Nouvelles données pour la chronologie du IIe millénaire, N.A.B.U. 2002/20.

\section{Michel 2003}

C. Michel, Old Assyrian Bibliography of Cuneiform Texts, Bullae, Seals and the Results of the Excavations at Assur, Kültepe/Kanis, Acemhöyük, Alishar and Bogazköy, OAAS I, PIHANS 97 (Leiden 2003).

\section{Michel 2004}

C. Michel, The perdum-mule, a Mount for Distinguished Persons in Mesopotamia during the II ${ }^{\text {nd }}$ millennium B.C., in: B. S. Frizell (ed.), Man and Animal in Antiquity, Acta Instituti Romani Regni Sueciae (Roma 2004) I94-204 (http://www.svenska-institutet-rom.org/pecus/ contents.html).

\section{Michel 2006a}

C. Michel, Femmes et production textile à Aššur au début du II millénaire avant J.-C., Techniques \& culture 46, 2006, 28I-297.

\section{Michel 2006b}

C. Michel, Les suidés dans la documentation de Kaniš au début du II millénaire avant J.-C., in: B. Lion - C. Michel (eds.), De la domestication au tabou: le cas des suidés au ProcheOrient ancien, Travaux de la Maison René-Ginouvès I (Paris 2006) I69-I80. 
Michel 2008a

C. Michel, Nouvelles données de géographie historique anatolienne d'après des archives récentes de Kültepe, in: K. Strobel (ed.), New Perspectives on the Historical Geography of Anatolia in the II and I millennium B.C., Eothen I6, 2008, 235-252.

Michel 2008b

C. Michel, Les pérégrinations des marchands assyriens en haute Mésopotamie et en Asie Mineure, Res Antiquae 5, 2008, 37I-388.

\section{Michel 2008c}

C. Michel, Etain et cuivre dans les archives commerciales du xixe siècle av. J.-C.: du commerce du métal à l'objet, Cahier des thèmes transversaux ArScAn VIII, 2006/2007, 59-65 (http://www.mae.u-parisıo.fr/cahiers/pdf/C8/C8_Michel.pdf).

\section{Michel 2008d}

C. Michel, Les Assyriens et leurs femmes anatoliennes, in: J. G. Dercksen (ed.), Anatolia and the Jazira during the Old Assyrian Period, OAAS 3, PIHANS III (Leiden 2008) 209-229.

\section{Michel 20I0a}

C. Michel, Les comptoirs de commerce assyriens en Anatolie: emprunts réciproques et acculturation, in: P. Rouillard (ed.), Portraits de migrants, portraits de colons II, Colloques de la Maison René-Ginouvès 6 (Paris 20IO) I-I2.

\section{Michel 2orob}

C. Michel, Deux textes atypiques découverts à Kültepe, JCS 62, 2010, 73-82.

\section{Michel 2012}

C. Michel, Subartu, RlA I3, 20I2, 225-227.

\section{Michel - Garelli 1996}

C. Michel - P. Garelli, Heurts avec une principauté anatolienne, WZKM 86, I996, 277-290.

\section{Michel - Garelli 1997}

C. Michel - P. Garelli, Tablettes paléo-assyriennes de Kültepe I (Kt 90/k) (Istanbul I997).

\section{Michel - Veenhof 2010}

C. Michel - K. R. Veenhof, The Textiles Traded by the Assyrians in Anatolia (I9th-I8th Centuries BC), in: C. Michel-M. L. Nosch (eds.), Textiles Terminologies in the Ancient Near East and the Mediterranean Area from the $3^{\text {rd }}$ to the $\mathrm{I}^{\text {st }}$ millennium BC, Ancient Textiles Series, Oxbow Books, (Oxford 2010) 210-27I.

\section{Miller 200I}

J. Miller, Anum-Hirbi and His Kingdom, AoF 28, 200I, 65-IoI.

\section{Müller-Karpe 1994}

A. Müller-Karpe, Altanatolisches Metallhandwerk (Neumünster I994).

\section{Nicola - Glew 1999}

J. Nicola - C. Glew, Assyrian Colony Period Fauna from Acemhöyük Level III: A Preliminary Analysis, BMECCJ II, I999, 93-I48. 


\section{Özgüç 1965}

N. Özgüç, Kültepe Mühür Baskılarında Anadolu Grubu/The Anatolian Group of Cylinder Seal Impressions from Kültepe, TTKY V/22 (Ankara I965).

Özgüç 1986

T. Özgüç, Kültepe-Kaniş II. Eski Yakındoğu'nun Ticaret Merkezinde Yeni Araştırmalar. New Researches at the Trading Center of the Ancient Near East. Türk Tarih Kurumu Yayınları V/4I (Ankara: Türk Tarih Kurumu Basimevi I986).

Özgüç 2003

T. Özgüç, Kültepe Kaniš/Neša. The Earliest International Trade Center and the Oldest Capital City of the Hittites (Istanbul 2003).

\section{Özgüç 2006}

N. Özgüç, Kültepe-Kaniš / Neša. Yerli Peruwa ve Aššur-imittī’nin oğlu Assur'lu Tüccar Ușurša-Ištar'ın Arişivlerine ait Kil Zarfların Mühür Baskıları / Seal Impressions on the Clay Envelopes from the Archives of the Native Peruwa and Assyrian Trader Ușur-ša-Ištar son of Aššur-imittī, TTKY V/50 (Ankara 2006).

\section{Sagona - Zimansky 2009}

A. Sagona - P. Zimansky, Ancient Turkey (London 2009).

\section{Sturm 200I}

Th. Sturm, Puzur-Annā - Ein Schmied des Kārum Kaniš, in: W. von Soldt et al. (eds.), K. R. Veenhof Anniversary Volume, PIHANS 89 (Leiden 200I) 47550I.

\section{Sturm 2008}

Th. Sturm, Allanu - Haselnüsse als Delikatesse im karum-zeitlichen Handel von Anatolien nach Nordmesopotamien (ca. I930-I730 v.Chr), AoF 35, 2008, 296-3II.

\section{Veenhof 2003}

K. R. Veenhof, Trade and Politics in Ancient Aššur. Balancing of Public, Colonial and Entrepreneurial Interest, in: C. Zaccagnini (ed.), Mercanti e Politica nel Mondo Antico (Roma 2003) 69-II8.

\section{Veenhof 2006}

K. R. Veenhof, Traveling in Ancient Anatolia: Two New Sources from Karum Kanesh, in: B. Avunç (ed.), Hayat Erkanal'a Armağan; Kültürlerin Yansıması. Studies in Honor of Hayat Erkanal; Cultural Reflections (Istanbul 2006) 778-783.

\section{Veenhof 2008a}

K. R. Veenhof, The Old Assyrian Period, in: J. Eidem - K. P. Veenhof - M. Wäfler (eds.) Mesopotamien. Annäherungen 5: The Old Assyrian Period, OBO I60/5, (Fribourg 2008) I3-264.

\section{Veenhof 2008b}

K. R. Veenhof, Across the Euphrates, in: J. G. Dercksen (ed.), Anatolia and the Jazira during the Old Assyrian Period, OAAS 3, PIHANS III (Leiden 2008) 3-29.

\section{Veenhof 2008c}

K. R. Veenhof, Some displaced Tablets from Kārum Kanesh (Kültepe), AoF 35, 2008, IO-27. 


\section{Veenhof (in print)}

K. R. Veenhof, Old Assyrian Traders in War and Peace, in: H. Neumann et al. (eds.), Krieg und Frieden im Alten Vorderasien, CRRAI 52, Münster, July I7-2I 2006 (in print).

\section{Wilhelm 2008}

G. Wilhelm, Hurrians in the Kültepe Texts, in: J. G. Dercksen (ed.), Anatolia and the Jazira during the Old Assyrian Period, OAAS 3, PIHANS III (Leiden 2008) I8I-I94.

\section{Yakar 1998}

Y. Yakar, Environmental Factors Effecting Urbanisation in Bronze Age Anatolia, in: J. Goodnick Westenholz (ed.), Capital Cities, Urban Planning and Spiritual Dimensions (Jerusalem I998) 99-I09.

\section{Yakar 2000}

Y. Yakar, Ethnoarchaeology of Anatolia. Rural Economy in the Bronze and Iron Ages. Tel Aviv University Monograph Ser I7 (Tel Aviv: Tel Aviv University, Institute of Archaeology 2000). 